\title{
Service Quality Measurement in Health Care System- A Study in Select Hospitals in Salem City, TamilNadu
}

\author{
Dr. R.Kavitha, M.com.,M.Phil.,Ph.D \\ Department of Commerce, Padmavani Arts\& Science College, Salem, Tamilnadu.
}

\begin{abstract}
In today's highly competitive situation, hospitals are increasingly realizing the need to focus on service quality as a measure to improve their competitive position. In this research paper, the researcher presents a service quality perception study undertaken in two hospitals in Salem city. In the study the SERVQUAL questionnaire was used for measurement of Gap 1 Viz., difference between management's perception of patients' expectations \& patients' expectations. An analysis covering a sample of 400 patients and 50 doctors revealed that a gap between managements' perception about patients' expectations and patients' expectations of service quality exists.
\end{abstract}

Keywords: Doctors, Health care, Hospitals, Patients, SERVQUAL

\section{Introduction}

\subsection{Health Care in India}

Health care is a big concern in India, the land of nearly 1.12 billion people ${ }^{1}$ and the second most populous country in the world. As the country is divided into several States, the State government has the onus to take care of the health of people in the State.

Since India is a developing country where a large section of population is below poverty line, health and hygiene are not up to the mark. It is reported that in India, annually 22 lakh infants and children die from preventable illnesses, 1 lakh mothers die during the child birth and 5 lakh people die of tuberculosis. Also around 5 million people suffer from HIV/AIDS and numerous others die of diarrhoea and malaria ${ }^{2}$. The plight of the least advantaged has been increasing because of the poor public health systems. The government hospitals and health care centers do not completely address to the needs of the poor.

On the other hand, the private health care institutions charge exorbitant amount of money, which automatically renders them beyond the reach of many. However, the private health care sector in India is flourishing at the cost of the public. According to some critics, the national policy of the country lacks specific measures to achieve the stated goals. For instance, there is no proper integration of the health care services with the wider socio-economic and social development. There is lack of nutritional support and sanitation and there is poor participation of the people and government officials at the local level. The Central government adopts the strategy of improving the health systems through five-year plans. It co-operates with the State Government for that purpose and for sponsoring major health programs.

The Central and State Governments share the expenditure they meet in providing health care to the people. In mid 1990s, the Government spent $6 \%$ of the $\mathrm{GDP}^{3}$ on health, which is one of the highest levels of expenditure in the developing nations. The Central and State Governments set the goals and strategies in consultation with the Central Council of Health and Family Welfare. The Ministry of Health and Family Welfare monitors the workings of the Central Government and provides technical and administrative services along with medical education.

According to a World Bank study the per capita spending on health in India is around Rs. 320 per year with a significant input of $75 \%$ from private households. The State Governments contribute $15.2 \%$, the Central Government $5.2 \%$, third party employers $3.3 \%$ and the municipal government and foreign donors provide about $1.3 \%$ to the total spending, of which $58.7 \%$ goes to primary health care (curative, preventive and promotional) and $38.8 \%$ is spent on the secondary and tertiary ones. ${ }^{4}$

Despite the efforts of the State and Central Governments efforts, the health care in India is in a bad condition because of several factors- the rapidly increasing population of the country, high level of corruption in government and non-government health care organizations and lack of awareness amongst people.

In India, the hospitals are run by government, charitable trusts and by private organizations. The government hospitals in rural areas are called the Primary Health Centers (PHCs). Major hospitals are located in district head quarters or major cities. Apart from the modern system of medicine, traditional and indigenous medicinal systems like Ayurvedic Siddah and Unani systems are in practice throughout the country. 


\subsection{Failure of Urban Health Care System}

Health Care System in India in the last 45 years has focused on increasing coverage in the rural areas. There has been little or no development of organized health care services for the vast urban areas. The 3,600 odd cities and towns of India with some 40 million people living in slums have to depend largely on private practitioners (mostly quacks) for their health care needs. Out of the 3,000 plus urban local bodies in India only about 100 have some semblance to a Health Care System service while the rest have only a sanitary inspector or even a lower functionary to look after the Health Care System. ${ }^{5}$

It is not uncommon to see medical colleges and hospitals belonging to various medical systems such as modern, ayurveda and homeopathy in one Indian city. India provides an excellent example of medical pluralism. People follow home remedies, spiritual remedies and treatment from various medical systems simultaneously or one after another. Metropolitan urban areas provide medical facilities, which are available in developing countries such as cardiac surgery, treatment of all kinds of cancers, or in brief, for the diseases which are associated with affluence. The major diseases identified in South - East Asia Region under WHO are malaria, filarial and other mosquito - borne diseases, diarrhoea diseases, leprosy, tuberculosis, sexually transmitted diseases, poliomyelitis and other children diseases, tetanus, nasopharyngeal and cervical cancers, visual impairment and blindness, etc.

The organized sectors in urban areas such as employees of government and public undertakings bargain for medical benefits like Employees State Insurance Scheme and Government Health Schemes. In some cases, medical expenses are reimbursable if treated at recognized hospitals. At the same time, there is a lot of overlap and even the private medical practitioners seem to thrive well simultaneously. However, the unorganized sector such as domestic workers, self-employed, porters, cart-pullers, load-carriers and urban poor mostly living in slums do not get these benefits. They are also deprived of piped water and modern sanitation, or in any case, the facilities are woefully inadequate.

Urban poor, whose hallmark in expenditure is cheapness, get adulterated food and drugs. On an average, milk, milk-products, edible oils, wheat flour, spices and even tea leaves are adulterated to the tune of 50 per cent.

Mental health has yet to receive due attention in India. While westernized urban elite requires the services of psychiatrists in increasing number, for others family continues to provide psychic treatment. If crime rate, suicide, divorce, riots and indiscipline are considered as parameters of mental health, then urban area needs urgent attention.

It is often said that a large proportion of population suffers from protein calorie malnutrition. However, the range of nutrition in which people can function efficiently without getting nutritional deficiencies is wide and what are commonly given, as recommended quantities for intake of nutrients are much higher than what are required.

Urban poor unfortunately use bottle feeding and baby feeds under the influence of commercial advertising on radio, television, and through other popular media like films.

The revolutions in drugs coincide with freedom from colonial rule. The drug industry has developed out of proportion in comparison with basic amenities like potable water and sanitation.

In India, drugs are only consumed among 20 per cent urban people. The per capita consumption is perhaps the lowest in the world. However, this code does not represent the correct picture in view of the fact that about 75 per cent population in rural areas and urban poor has yet to have access to drugs. Major share of these drugs are taken away by vitamins, tonics, and antibiotics. It is estimated that out of the total production 25 per cent is taken away by vitamins and tonics, and 20 per cent by antibiotics.

\section{Statement of the Problem}

Healthcare services have a distinct position among other services due to the highly involving and risky nature of service. Though a large number of public and private hospitals are existing all over the country, it is found that many government hospitals are not able to provide quality services to patients. Further more the private hospitals also are not able to fulfill the requirements of the patients to a certain extent. The main problem of hospitals is that they are not able to provide quality service based on the needs and expectations of the patients.

One of the main problems is lack of adequate and timely medical treatment to patients. The other problems are non-availability of medical facility, inadequate competent doctors, nurses and employees, etc. The majority of the population in India lives in the rural areas who are not aware of the diseases generated by water, bad sanitation and food.

Many people are affected by pollution. In Delhi, about 12 percent of children in the age group of five to sixteen were suffering from bronchitis $^{6}$. In Calcutta, 10647 people suffered premature death due to air pollution 7 . In Mumbai too it is found of the air toxic. The concentration of lead and respirable dust in the city's air has reached dangerous levels exceeding limits prescribed by National Air Quality Standards and the $\mathrm{WHO}^{8}$. 
Further, a majority of people are affected by heart disease, tuberclosis, dengue fever, AIDS, blood cancer, etc. The government hospitals have found that they are not able to fulfill the healthcare requirements of the people and the rural health centres virtually become non-existent. But even in private hospitals, the quality of medical care is not satisfactory, though they charge high fees.

Medical care has not become affordable ${ }^{9}$, not only for the $26 \%$ of the Indian population who live below poverty line, but also for the middle income group. A major problem in the Indian health care delivery system is found to be lack of equipment and diagnostic tools which have to be imported from other countries.

The government hospitals are found that they are not able to fulfill the health care requirements of the people and the rural health centers have virtually become non-existent. Buildings are there, equipments are there, patients are there, but the doctors, of course, on record are also there but actually they are busy in their private clinics. The patients do not get medical aid since major surgical items are not found only in the stores. The premises have a dirty look and the environmental conditions are prone to disease. The more critical situation is found in rural areas since poorer sections of the society fail in getting the services of rural health centers. Hence private hospitals have come into existence in order to avoid the poor quality of service in government hospitals. But even in private hospitals, the quality of medical care is found not satisfactory, though they charge high fees.

In this context the following questions arise:

1. What is the extent to which the hospitals are able to meet the patients' expectations?

2. What is the difference between the expected service and the perceived service of the patients?

3. What is the extent to which the managements of hospitals have understood the perceptions of the patients in providing service?

4. What are the important dimensions of service quality of the hospitals and their relative importance? Of the above, in this study, an attempt is made to study and find an answer to the issue, viz., extent to which the managements have understood the perceptions of the in providing service.

In this study, the SERVQUAL instrument has been specifically adopted to measure service quality using both the gap concept and service quality dimensions. The main aim of the study is to measure the patients' perceptions and expectations of service quality in the two hospitals selected for the study, using the multidimensional, generic, internationally used and accepted market research instrument called SERVQUAL ${ }^{10}$. It consists of five dimensions viz., tangibles, reliability, responsiveness, assurance and empathy.

SERVQUAL instruments contain two sections: a 22 item section that records patients' expectations of quality of service provided in the hospitals and another 22 item section that measures patients' perceptions on the quality of the hospitals. Opinions from these sections are measured on a Likert seven point scale, with the anchor labels of "Most strongly disagree" to "Most strongly agree".

Further, the same instrument has been used to measure the management's perceptions about patients' expectations across the two select hospitals. Monetary considerations i.e., charges payable to the hospital for the service provided is not considered, as this study is concerned with measuring of service quality. Hence no other technique except the SERVQUAL model provided by Parasuraman has been used to measure the service quality provided by the hospitals.

\section{Objectives of the Study}

The main objective of the study is to analyze the quality of service provided by the hospital sector. The specific objective of the study is

* To compare the Management's perceptions of patients' expectations and the patients' expectations.

\subsection{Service Quality}

\section{Concepts used}

Service Quality means "Meeting or exceeding the expectations of customers" (Quester and Romaniuk, 1997) ${ }^{11}$. The concept "Service Quality" means perceptions of any individual / patient about the technical outcome or service provided, the process by which the service is delivered and the quality of surrounding where the service is delivered. The quality of service provided in the hospital is based on the factors / dimensions such as Tangibles, Reliability, Responsiveness, Assurance and Empathy. These five dimensions represent how patients organize information about service quality in their minds.

\subsection{Patient Satisfaction}

\subsection{Expectation}

When expectations of service quality are exceeded, patient satisfaction is realized.

\subsection{Gap}

What patients feel or desire the service provider (hospital) should offer.

\subsection{Perceived Service Quality}




\subsection{SERVQUAL 1996)..$^{12}$ \\ A multiple item scale for measuring consumer perceptions of service quality (Asubonteng et. al.,}

The patients' judgment about an hospital's overall excellence or superiority.

\subsection{Management's Perceptions about Patients Expectations}

Management's perceptions about patients expectations refer to the perceptions of the doctors working in the hospital about the expectations of the patients.

\section{Hypotheses}

Based on the theoretical knowledge gained by the researcher while surveying the literature and the previous studies available and interactions she had with experts on the subject and with the hospital authorities, the following hypotheses have been formulated for the study. They are:

$>$ Management's Perceptions of Patients' Expectations and the Patients Expectations do not differ significantly.

$>$ Management's perceptions of patients' expectations of service quality among the two hospitals do not differ significantly.

\section{Methodology and Tools}

This study is an empirical research based on survey method. Data required for this study are both primary and secondary. Primary data relating to patients of the hospital are collected through personal interview with the patients and secondary data relating to the hospitals are collected from the records of the select hospitals. The researcher had personal discussions with the patients of the hospitals, and they were personally contacted and interviewed to elicit relevant information. The interview schedule used by Parasuraman, et. al., $(1988)^{13}$ is adopted for the study.

Moreover, the data also are collected from doctors of the hospitals using a questionnaire to know about the management's perceptions of patients' expectations.

The important attributes are classified into five dimensions based on the SERVQUAL model developed by Parasuraman for measuring the service quality. The interview schedule using SERVQUAL model consists of 44 items: each having two sections: One, the expectations of the patients from the hospitals and the other, the perceptions of the patients. The questionnaire for doctors also consists of 22 items on management's perceptions of patients' expectations.

\section{Sampling Scheme}

Two hospitals in Salem are purposively selected for the study, ie., one private hospital and another public hospital. The private hospital is Sri Gokulam hospital (P) Ltd., and the public hospital is Mohan Kumaramangalam Government Medical College Hospital. In these two hospitals, a sample of 400 in-patients (each having 200 samples) are selected to measure the patients' perception of service quality. As the population frame cannot be properly defined during the period of collection of data with regard to the patients admitted in the hospital, the researcher has to approach the patients who are available in the hospital at the time of interview. The respondent patients whom the researcher met accidentally are included in the sample. Hence the sampling technique used in this study is non-probability sampling and the respondents are selected on the basis of convenience sampling but are selected from different units of the select hospitals to get a more holistic view. Hence the sample design is not free from the defects of convenience sampling but there is no other alternative than to use the convenience sampling.

To study the management's perceptions of patients' expectations, out of 100 distributed questionnaires among the two hospital doctors, 50 responses (20 from Sri Gokulam hospital and 30 from Medical College hospital) are received and analyzed.

TABLE - 1

SAMPLE SIZE

\begin{tabular}{|l|l|c|c|c|c|}
\hline S. No & Nature of Hospital & $\begin{array}{c}\text { No. of } \\
\text { Beds }\end{array}$ & $\begin{array}{c}\text { Sample } \\
\text { size of } \\
\text { patients }\end{array}$ & $\begin{array}{c}\text { No. of } \\
\text { doctors }\end{array}$ & $\begin{array}{c}\text { Sample } \\
\text { size of } \\
\text { doctors }\end{array}$ \\
\hline 1 & Private Hospital & 200 & 200 & 30 & 20 \\
2. & Public Hospital & 831 & 200 & 84 & 30 \\
\hline & Total & - & 400 & 114 & 50 \\
\hline
\end{tabular}

VIII. Fieldwork and Data Collection 
The fieldwork for the study was conducted for about 3 months during 2009. A large number of rooms are available in the two hospitals, which are classified into different sections according to the speciality. In these rooms, the patients are admitted based on the disease and the capacity and willingness of patients. Patients are interviewed while they are about to be discharged from the hospitals.

The interview schedule constructed is the main tool for data collection. The patients are given sufficient time to answer without any disturbance. Patients are selected in a "Just hit and miss" fashion when they are in the rest time in the room. Further, the questionnaire constructed for collecting data from doctors is distributed to 100 doctors working in the two hospitals and they are requested to answer them during their leisure time and they are assured that their responses would be kept confidential. Though all the doctors are distributed questionnaires, only 50 doctors (20 from Sri Gokulam Hospital and 30 from Government Medical College Hospital) return the duly filled-in questionnaire. Hence the sample size of doctors is only 50.

\section{Results and Discussions}

9.1 Average scores of Management's perceptions, patients expectations and their differences for the Public and Private hospitals

The mean scores of Management's perceptions about patients expectations and patients expectations of the Public and Private hospitals are given in the table 2

TABLE - 2

Average Scores Of Management's Perceptions, Patients Expectations And Their Gap (Public And Private Hospitals)

\begin{tabular}{|c|c|c|c|c|c|c|}
\hline \multirow{2}{*}{ Service Quality Dimensions } & \multicolumn{2}{|c|}{ M } & \multicolumn{2}{|c|}{ E } & \multicolumn{2}{|c|}{ M-E } \\
\hline & Mean & $\%$ & Mean & $\%$ & Mean & $\%$ \\
\hline Tangibles & & & & & & \\
\hline $\begin{array}{l}\text { Excellent hospitals will have } \\
\text { modem looking equipment }\end{array}$ & 6.26 & 89.43 & 5.38 & 76.70 & 0.89 & 12.64 \\
\hline $\begin{array}{l}\text { The physical facilities of } \\
\text { excellent hospitals are } \\
\text { visually appealing }\end{array}$ & 6.80 & 97.14 & 5.35 & 76.39 & 1.45 & 20.75 \\
\hline $\begin{array}{l}\text { Personnel at excellent } \\
\text { hospitals will be neat in } \\
\text { appearance }\end{array}$ & 6.28 & 89.71 & 5.16 & 73.64 & 1.13 & 16.07 \\
\hline $\begin{array}{l}\text { Materials associated with the } \\
\text { services will be visually } \\
\text { appealing in an excellent } \\
\text { hospitals }\end{array}$ & 6.22 & 88.86 & 5.22 & 74.50 & 1.01 & 14.36 \\
\hline Reliability & & & & & & \\
\hline $\begin{array}{l}\text { When excellent hospitals } \\
\text { promise to do something by a } \\
\text { certain date, they do so }\end{array}$ & 6.02 & 86.00 & 5.30 & 75.64 & 0.73 & 10.36 \\
\hline $\begin{array}{l}\text { When a patient has a problem, } \\
\text { excellent hospitals will show } \\
\text { a sincere interest in solving it }\end{array}$ & 6.28 & 89.71 & 5.16 & 73.75 & 1.12 & 15.96 \\
\hline $\begin{array}{l}\text { Excellent hospitals will be } \\
\text { dependable }\end{array}$ & 6.30 & 90.00 & 5.21 & 74.46 & 1.09 & 15.54 \\
\hline $\begin{array}{l}\text { Excellent hospitals will } \\
\text { provide their services at the } \\
\text { time they promise to do so }\end{array}$ & 6.24 & 89.14 & 5.09 & 72.71 & 1.15 & 16.43 \\
\hline $\begin{array}{l}\text { Excellent hospitals will get } \\
\text { the things right the first time }\end{array}$ & 6.52 & 93.14 & 5.18 & 73.97 & 1.34 & 19.17 \\
\hline Responsiveness & & & & & & \\
\hline $\begin{array}{l}\text { Personnel in excellent } \\
\text { hospitals will tell patients } \\
\text { exactly when services are } \\
\text { provided }\end{array}$ & 6.30 & 90.00 & 5.17 & 73.86 & 1.13 & 16.14 \\
\hline $\begin{array}{l}\text { Personnelin excellent } \\
\text { hospitals will give prompt } \\
\text { services to patients }\end{array}$ & 6.38 & 91.14 & 5.20 & 74.25 & 1.15 & 16.89 \\
\hline $\begin{array}{l}\text { Personnel in excellent } \\
\text { hospitals will always be } \\
\text { willing to help patients }\end{array}$ & 6.52 & 93.14 & 5.13 & 73.25 & 1.39 & 19.89 \\
\hline
\end{tabular}


Service Quality Measurement in Health Care System- A study in select hospitals in Salem city,

Tamilnadu

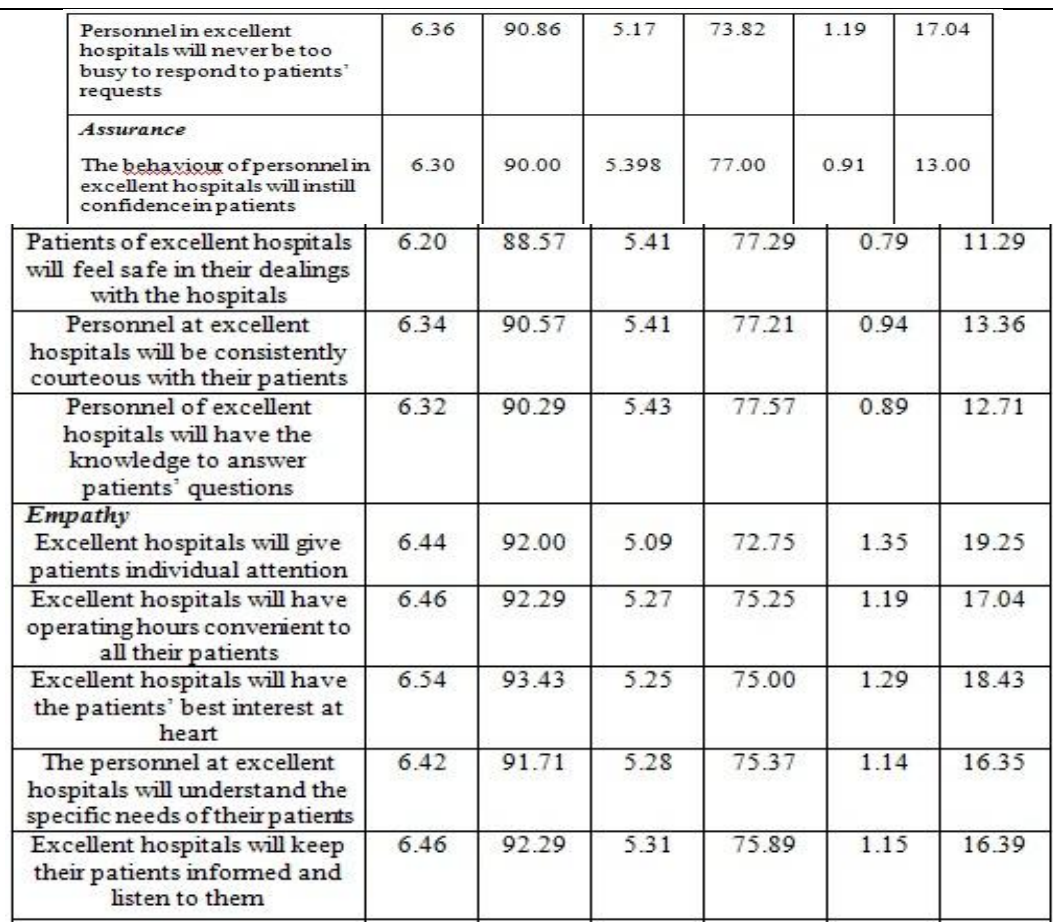

M - Indicates Management's perceptions about patients expectations E - Indicates patients expectations

Table 2 shows that the mean scores of management's perceptions is the highest (6.80) for "physical facilities are visually appealing" and the mean scores are between 6 and 7 for all the statements. The average scores of patients expectations are between 5 and 6 for all the 22 statements under all the five dimensions. The average gap scores between management's perceptions about patients expectations and patients expectations are positive for all the 22 items. The positive scores are close to ' 0 ' and ' 1 ', which indicates that the managements have good understanding of the patients expectations.

9.2 Aggregate Dimensional scores and overall Gap Scores -' $t$ ' test

The aggregate dimensional scores and the overall gap scores are reported in the table

TABLE -3

DIMENSION-WISE AVERAGE SCORES OF MANAGEMENT'S

PERCEPTIONS ABOUT PATIENT EXPECTATIONS AND PATIENT EXPECTATIONS - 't' ' TEST (PUBLIC AND PRIVATE HOSPITALS)

\begin{tabular}{|c|c|c|c|c|c|c|c|c|c|}
\hline Dimensions & Group & $\mathrm{N}$ & $\begin{array}{l}\text { Mean } \\
\text { Scores }\end{array}$ & S.D. & $\begin{array}{c}\text { Std. } \\
\text { Error }\end{array}$ & $\begin{array}{c}\text { 't' } \\
\text { value }\end{array}$ & df & $\begin{array}{c}\text { 'p' } \\
\text { value }\end{array}$ & Result \\
\hline \multirow{2}{*}{ Tangibles } & Patient & 400 & 21.09 & 2.766 & 0.138 & \multirow{2}{*}{-8.541} & \multirow{2}{*}{448} & \multirow{2}{*}{0.000} & \multirow{2}{*}{$\begin{array}{l}\text { Highly } \\
\text { Significan }\end{array}$} \\
\hline & Doctor & 50 & 24.60 & 2.499 & 0.353 & & & & \\
\hline \multirow{2}{*}{ Reliability } & Patient & 400 & 25.93 & 3.584 & 0.179 & \multirow{2}{*}{-7.754} & \multirow{2}{*}{448} & \multirow{2}{*}{0.000} & Tighly \\
\hline & Doctor & 50 & 30.06 & 3.316 & 0.469 & & & & Significant \\
\hline \multirow{2}{*}{ Responsiveness } & Patient & 400 & 20.66 & 2.953 & 0.148 & \multirow{2}{*}{-9.487} & \multirow{2}{*}{448} & \multirow{2}{*}{0.000} & \\
\hline & Doctor & 50 & 24.80 & 2.507 & 0.355 & & & & Significant \\
\hline \multirow{2}{*}{ Assurance } & Patient & 400 & 21.64 & 3.299 & 0.165 & \multirow{2}{*}{-4.581} & \multirow{2}{*}{448} & \multirow{2}{*}{0.000} & \multirow{2}{*}{$\begin{array}{l}\text { Highly } \\
\text { Significan }\end{array}$} \\
\hline & Doctor & 50 & 23.88 & 2.994 & 0.423 & & & & \\
\hline \multirow{2}{*}{ Empathy } & Patient & 400 & 26.19 & 3.616 & 0.181 & \multirow{2}{*}{-7.770} & \multirow{2}{*}{448} & \multirow{2}{*}{0.000} & \multirow{2}{*}{$\begin{array}{l}\text { Highly } \\
\text { Significan }\end{array}$} \\
\hline & Doctor & 50 & 30.44 & 3.924 & 0.555 & & & & \\
\hline \multirow{2}{*}{$\begin{array}{c}\text { Overall } \\
\text { dimensions }\end{array}$} & Patient & 400 & 115.50 & 12.527 & 0.626 & \multirow{2}{*}{-10.104} & \multirow{2}{*}{448} & \multirow{2}{*}{0.000} & \multirow{2}{*}{$\begin{array}{l}\text { Highly } \\
\text { Significant }\end{array}$} \\
\hline & Doctor & 50 & 133.78 & 7.223 & 1.022 & & & & \\
\hline
\end{tabular}


The ' $t$ ' values for all the dimensions are significant and hence it can be concluded that both the managements of the public and private hospitals have a good understanding of the patients' expectations. All the above reveal that both the managements of public and private hospitals overestimate patients' expectations in providing services.

\subsection{Management's perceptions of patients' expectations for the public and private hospitals}

To ascertain the nature of relationship between the management's perceptions of patients expectations among the two hospitals statistically, t-test is applied to test the hypothesis "there is no significant difference in management's perceptions of patients“ expectations of service quality among the two hospitals".

\section{GAP SCORES OF MANAGEMENT'S PERCEPTIONS OF PATIENTS EXPECTATIONS FOR THE PUBLIC AND PRIVATE \\ HOSPITALS - ' $t$ '-TEST}

\begin{tabular}{|c|c|c|c|c|c|c|c|c|c|}
\hline Dimensions & Group & $\mathbf{N}$ & $\begin{array}{l}\text { Mean } \\
\text { Scores }\end{array}$ & S.D. & $\begin{array}{c}\text { Std. } \\
\text { Error }\end{array}$ & $\begin{array}{c}\text { 't' } \\
\text { value }\end{array}$ & df & $\begin{array}{c}\text { 'p' } \\
\text { value }\end{array}$ & Result \\
\hline \multirow{2}{*}{ Tangibles } & Public & 30 & 24.13 & 2.556 & 0.467 & \multirow{2}{*}{$\begin{array}{c}- \\
1.645\end{array}$} & \multirow{2}{*}{48} & \multirow{2}{*}{0.106} & Not \\
\hline & Private & 20 & 25.30 & 2.296 & 0.514 & & & & Significant \\
\hline \multirow{2}{*}{ Reliability } & Public & 30 & 29.53 & 3.693 & 0.674 & \multirow{2}{*}{$\begin{array}{c}- \\
1.388\end{array}$} & \multirow{2}{*}{48} & \multirow{2}{*}{0.171} & Not \\
\hline & Private & 20 & 30.85 & 2.540 & 0.568 & & & & Significant \\
\hline \multirow{2}{*}{ Responsiveness } & Public & 30 & 24.87 & 2.515 & 0.459 & \multirow{2}{*}{0.228} & \multirow{2}{*}{48} & \multirow{2}{*}{0.821} & Not \\
\hline & Private & 20 & 24.70 & 2.557 & 0.572 & & & & Significant \\
\hline \multirow{2}{*}{ Assurance } & Public & 30 & 24.13 & 2.991 & 0.546 & \multirow{2}{*}{0.729} & \multirow{2}{*}{48} & \multirow{2}{*}{0.469} & Not \\
\hline & Private & 20 & 23.50 & 3.035 & 0.679 & & & & Significant \\
\hline \multirow{2}{*}{ Empathy } & Public & 30 & 30.27 & 3.973 & 0.725 & \multirow{2}{*}{$\begin{array}{c}- \\
0.379\end{array}$} & \multirow{2}{*}{48} & \multirow{2}{*}{0.706} & Not \\
\hline & Private & 20 & 30.70 & 3.935 & 0.880 & & & & Significant \\
\hline \multirow{2}{*}{$\begin{array}{c}\text { Overall } \\
\text { dimensions }\end{array}$} & Public & 30 & 132.933 & 7.366 & 1.345 & \multirow{2}{*}{$\begin{array}{c}- \\
1.015 \\
\end{array}$} & \multirow{2}{*}{48} & \multirow{2}{*}{0.315} & Not \\
\hline & Private & 20 & 135.050 & 6.992 & 1.563 & & & & Significant \\
\hline
\end{tabular}

' $\mathrm{t}$ ' test result in the table 4 shows that there is no significant difference in the overall gap score among the two hospitals. In the case of dimensions Responsiveness and Assurance, the mean values of the management's perceptions of patients expectations of the private hospital are lower than that of the public hospital. However, as the ' $t$ ' values of all the dimensions and overall dimensions are not significant, there is no difference in management's perceptions about patients expectations of service quality among the public sector hospital and the private sector hospital. It can be concluded that fairly large gap score shows that the managements have a good understanding of the patients' expectations.

\section{Findings}

The measure of gap between the management's perceptions of patient expectations and the patients' expectations of service quality are studied in this study. The perceptions of the Doctors representing the management about the patients expectations of service are very high when compared to the patients expectations in both hospitals. Aggregate mean values of the two hospitals are calculated and it is found that for all the dimensions, there is significant difference between the mean scores of management's perceptions of patient expectations and patients expectations. However, as between the hospitals, there is no significant difference between the hospitals in the doctors perceptions about patients expectations.

\section{Conclusion}

The main focus of the study is to understand what patients' expectations are for service quality which can help shape a hospital's health care service delivery to better meet patients' needs and desires. The management's perceptions of expectations of the patients have been measured. All these enable the health care system to understand their strength and weaknesses in the delivery of health care to the patients.

[1]. www.healthcareindia.net

\section{References}

[2]. Ibid.,

[3]. www.healthcareindia.net

[4]. Ibid.,

[5]. www.ananthapuri.com

[6]. Rashtriya Sahara : Choked Existence : Degradig Environment in Making earth a hell, January, 1998, pp.145-147.

[7]. Ibid., pp.145-147.

[8]. Ibid., pp.145-147

[9]. Abdul Kalam,A.P.J. and Sivathanu Pillai,A., Envisoning and Empowered Nation, New Delhi: Tata McGraw Hill Publishing Co Ltd., 2004. 
Service Quality Measurement in Health Care System- A study in select hospitals in Salem city,

Tamilnadu

[10]. $\quad$ Parasuraman.A, Zeithaml V.A and Berry L.L (1988) SERVQUAL : A Multiple Item scale for measuring customer perceptions of service quality, Journal of Retailing 64 : Spring, pp.12-40.

[11]. Quester, P.G and Romaniuk, S (1997), Service Quality in the Australian Advertising Industry: A Methodological Study", The Journal of Services Marketing” 11(3), pp.180-192.

[12]. Asubonteng, K. McCleary, J. and Swan J.E (1996), SERVQUAL revisited; A Critical Review of Service Quality, The Journal of Services Marketing, 10(6), pp.62-81.

[13]. Parasuraman et. al., (1988) Op. Cit., pp. 12-40

[14]. Jha.S.M., Service Marketing,Mumbai:Himalaya Publishing House 2003

[15]. Krisnasamy,O.R.and Ranganathan.M.,Methodology of Research In Social Science,Mumbai,Himalaya Publishing House,2005. 